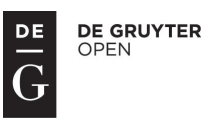

\title{
QUESTIONING THE MORAL UNDERSTANDING OF LAW
}

\section{Marijan Pavěnik ${ }^{1}$}

\begin{abstract}
The primary content-related framework we are bound to are the basic human rights as established in the constitution. These basic rights may change and develop, yet as the heritage of our political and legal culture, they possess such a solid core meaning that only a "dogmatic sceptic" (G. Radbruch) can doubt it. In societies with plural values, the moral values expressed by the basic human rights are the most solid moral basis of law. The moral understanding of law is necessarily accompanied by a moral criticism of law. Such criticism is often not pleasing to the authorities, but it cannot be avoided if one wants to live up to our responsibility towards nature, society and future generations. A lawyer who is not interested in these issues and only sticks to the letter of the law acts in a fossilized manner and does not enrich the life that the law is intended for. Legal thought should always have its meaning, as Smole's Antigone would say.
\end{abstract}

\section{Keywords}

Moral Understanding of Law, Legal Positivism, Basic Human Rights, Moral Charge of Law, Acting lege artis, Moral Criticism of Law

\section{Introduction}

Boris Furlan somewhere says: Ethics is "potential law - law is topical ethics".2 This thought must not be understood literally. A literal understanding would mean that law and morality have - within the extent where they overlap - identical characteristics. Thought about morality as the possible and future law and about the law as the current morality is a metaphor that must not conceal the important differences existing between law and morality. If we follow Kant, certainly the fundamental difference is that the law refers to man's external behaviour (the so-called external lawgiving), whereas moral rules are internalized and based on man's morality (Germ. Sittlichkeit). ${ }^{3}$

\footnotetext{
${ }^{1}$ Faculty of Law, University of Ljubljana, Poljanski nasip 2, 1000 Ljubljana, Slovenia. E-mail: Marijan.Pavcnik@pf.uni-lj.si.

${ }^{2}$ Furlan (1921, p. 22).

${ }^{3}$ See Kant (1990, p. 53 [219]).
} 
Kant expressly states that one can imagine external lawgiving comprising only positive laws, "but then a natural law would still have to precede it, which would establish the authority of the lawgiver (i.e., his authorization to bind others by his mere choice)". 4

The issue of morality of law is also of great importance when it comes to the understanding of statutes and the application thereof in concrete cases. A practical interpretation of the statute is necessarily a moral act as well. If we are aware of it and admit it, it is urgently required that we do not overstep the natural differences between law and morality. It is equally important to consider only generally accepted moral conceptions that can be standardized (e.g. at the understanding of emotional distress for which monetary compensation is allowed). It would be unacceptable if the interpretation of the statute were to harbour moralising or to give priority to any extreme moral conceptions. The morality of law requires rising over single cases and generalising them (the principle of equality!). Between law and morality there always exists an appropriate tension, which is a part of the moral and legal play. The tension is productive when it strengthens the morality of law and non-creative when it stifles morality where the law ought to respect it and build upon it (e.g. in the confidential relation between a patient and a doctor). This group of problems contains the issues dealt with in the continuation. They refer, e.g. to the nature of legal positivism, to basic human rights as the modern natural law, to basic human rights as legal principles, to the meaning of man's freedom, to generalization as transformation and to the moral charge of law.

\section{The issue of legal positivism}

The fact that positive law must have ethical foundations if it wants to assert oneself and to be effective in the long run, does not exclude legal positivism. The latter really separates law and morality (the so-called separability thesis), yet not because it would not be aware that the law must have moral foundations, but simply because its object of investigation is merely the positive law. Pure legal positivism tries to answer "the questions of what the law is and how the law is made, not the questions of what the law ought to be or how the law ought to be made". 5

Legal positivism can be considered corrupt if it justifies just any positive law irrespective of its possible lack of morality. Actually, this is not legal positivism as a science, but an apologetic legal positivism as a servant of politics. Scientific legal positivism has other and different ambitions. Its ambition is to expose the valid law and to try to show it as it is. We have a clearing before us where it can be distinctly seen who the players are and what possibilities they have when making legal decisions.

Positivism of this kind does not bother me at all. I even believe that such positivism is wholly compatible with those views about law that deal with content-related issues. A prerequisite for a content-related discussion is a good knowledge of the valid law, of its structure and of its possible meanings.

\footnotetext{
${ }^{4}$ Kant (1990, p. 60 [224]). The English quotation is taken from Kant (1996, p. 17).

${ }^{5}$ Kelsen (1992, p. 7).
} 


\section{Basic human rights as the modern natural law}

Nobody acting in the arena of legal life can avoid moral issues. He must be blind who thinks that he can make legal decisions without solving moral issues as well.

We are on slippery ground. The primary content-related framework we are bound to are the basic human rights as established in the Constitution. The basic human rights are a heritage of our civilisation and legal culture, which boasts such a solid and far-reaching consensus that only a "dogmatic sceptic" (G. Radbruch) ${ }^{6}$ could doubt it. The catalogue of these rights in the Constitution is an achievement of rationalistic natural law entering the constitutional law. ${ }^{7}$ The law of basic human rights is no supra-statutory law, but an integral part of positive (constitutional) law.

It lies in the nature of basic human rights that, as a tradition, they represent the moral foundation of the law and, as a legal (constitutional) act, they represent, as to their content, a sufficiently open framework, which can be further developed. This also applies to the basic constitutional principles. The basic human rights are connected to these principles (e.g. to the principle of the rule of law) and, to a considerable extent, they themselves possess the nature of principles.

\section{Basic human rights as legal principles}

It is said about legal principles that they are "value measures directing the definition of legal rules as to their contents, the understanding of the rules, and the manner of their application". 8 Practically all basic rights comprise principles outlining the goal, the weight and the scope of single rights. The goal of a right (e.g. of the right to social security) defines the direction its constitutional and statutory regulation should take. If the direction towards the goal slips under a tolerable minimum, the content of the right is not in conformity with the Constitution any more.

The weight and the scope of basic human rights are also important. The weight of the rights is especially sensitive when a conflict of two or more rights arises (e.g. a conflict between the protection of privacy and the freedom of expression). It depends on the weight of the rights whether one right should have priority over the other or both rights can suitably coexist. And here is also the constitutional scope of the rights (e.g. the scope of the freedom of the press). A right is only constitutionally exercised if it remains within the constitutional semantic field. The boundary of this field must be true to the core meaning of the right. If this fidelity is not given and, for example, the freedom of the press loses the sharpness of serious criticism (e.g. caricatures), which is a necessary component of cultured communication, and passes into the humiliation of the other, we are already beyond the scope that is in conformity with the constitution.

In societies with plural values, the moral values expressed by the basic human rights are the most solid moral basis of the law. Admittedly, this basis is rather diverse, but the law as its binding material gives it a sufficiently solid content direction and legal remedies to

\footnotetext{
${ }^{6}$ Radbruch (2006, p. 15).

${ }^{7}$ See Hassemer (2002, p. 135-150).

${ }^{8}$ Pavčnik (2013, p. 130).
} 
solve conflicts if and when they cannot be solved voluntarily. The actual situation of basic human rights is not ideal, yet these rights represent that minimum of morality that the law stands with by protecting and developing it further and falls with by not respecting it or even trampling on it.

\section{The meaning of man's freedom}

Thus, legally protected basic human rights are the necessary normative framework needed by man as a free being. Freedom is the fundamental presupposition of the existence and the condition allowing man to make decisions. Next to man's freedom is the freedom of the other, which he has to respect and coexist with. The lack of this coexistence or a considerable narrowing thereof also narrows the room for making decisions. Already Kant spoke about it in a very convincing manner. For him, the law is also "the sum of the conditions under which the choice of one can be united with the choice of another in accordance with the universal law of freedom". 9

The sharp distinction between morality and law is possible on the conceptual level, whereas on the concrete level they are two phenomena influencing each other. It is of special importance for the understanding of the law that the respect for the law as well as its effectiveness largely depend on the moral valuation of the law. A law that turns a deaf ear to the values of basic human rights is foredoomed to failure. It is of no lesser importance how the constitution, the laws and other legal acts are interpreted. It lies in the nature of interpretation that it is value-based and that it often possesses adequate room for making decisions co-defined by morality.

In a state governed by the rule of law, the legal decision-maker must always act in such a way as if he had an indefinite number of equal cases in front of him. ${ }^{10}$ It is an essential feature of such decision-making that the decision-maker (e.g. the judge) generalizes his standpoint in a concrete case and that the standpoint shaped in such a way is also valid for new cases essentially matching the decided one(s). The adopted standpoint may be changed for new and convincing (better) reasons. They must be explicitly and coherently stated in the substantiation of the decision.

\section{Generalization as transformation}

The above-mentioned issue of generalization is a special transformation that keeps occurring all the time in legal and court practice. If the central reason of the transformation is a moral value allowed by the meaning framework of the decision-making, we see the influence of morality upon law, i.e. an influence when the morality co-defines the content of law. The transformation that occurred begins to have its own independent life and thus, in its own way, leaves the moral values having co-shaped it. New meanings and their moral valuation result in new variants as to the meaning and they may also lead to a situation where the uniform and established legal (e.g. court) practice has to be supplemented and changed.

\footnotetext{
${ }^{9}$ Kant (1990, p. 66-67 [230]). The English quotation is taken from Kant (1996, p. 24).

${ }^{10}$ See the Slovenian Courts Act: "The judge has to decide in such a way as if he had an indefinite number of equal cases in front of him". (Art. 3/3).
} 


\section{The moral charge of law}

A special issue is the morally-charged value and process elements of the law. Using the language of Nikola Visković, I am thinking of the value and process elements justifying the content of legal regulation ${ }^{11}$ and at the same time allowing legal decision-making. Let us take the characteristics of general and abstract legal norms that can ensure legal equality, legal predictability and legal security. Equality, predictability and security are certainly moral values as well. Further, let us take it that laws and other legal sources have to be published, that, as a rule, they must not be retroactive and that the rights and obligations of legal subjects have to be defined in a relatively certain manner. Mutatis mutandis this also applies to the jurisdiction of state authorities and to all those limitations and prohibitions which are meant to prevent the arbitrary and inconsistent behaviour of these authorities. And, last but not least, there are process norms giving a framework to the legal play and contributing to fair play. An example of fair legal play is the rational legal discourse promoted by the theory of legal argumentation. ${ }^{12}$

\section{Conclusion}

It is wrong to expect the structural and process characteristics of the law to automatically produce high-quality (also moral) law. These characteristics do not possess such power, yet they can certainly contribute in an intensive manner to a high quality of legal decisions. And this is the main point. The lawyer's professional morality demands of him to act lege artis and to consider all characteristics and elements of law that are a conditio sine qua non for legal acts (e.g. laws) being balanced as to their content and nomotechnically refined.

Another important issue is the moral criticism of law, which is necessary whenever positive law and its solutions are not in accordance with the generally accepted moral values, with moral tolerance and with moral freedom that is also to be protected by the law. Such criticism is often not pleasing to the authorities, but it cannot be avoided if one wants to bear responsibility towards nature, society and future generations. A lawyer who is not interested in these issues and only sticks to the letter of the law acts in a fossilized manner and does not enrich the life that the law is intended for. Legal thought should always have its meaning, as Smole's Antigone would say. ${ }^{13}$

\footnotetext{
${ }^{11}$ See Visković (1981, p. 135). See also Pavčnik (2015, p. 504 ff.).

${ }^{12}$ Compare with the criteria discussed as the elements of the internal morality of law by Fuller (1972, p. $33 \mathrm{ff}$.).

${ }^{13}$ Smole (1988, Verse 118): "[S]he seeks the inmost meaning of some thought".
} 


\section{References}

Fuller, L. L. (1972). The Morality of Law. Revised edition. New Haven, London: Yale University Press.

Furlan, B. (1921). Pravo in etika (Law and Ethics). Pravni vestnik (Trst), 1(3-4), 17-23. Hassemer, W. (2002). Naturrecht im Verfassungsrecht. In A. Donatsch, M. Forster in Ch. Schwarzenegger (eds.). Strafrecht, Strafprozessrecht und Menschenrechte. Festschrift für Stefan Trechsel zum 65. Geburtstag. Zürich: Schulthess Verlag, 135-150.

Kant, I. (1990). Die Methaphysik der Sitten. Stuttgart: Reclam.

Kant, I. (1996). The Methaphisics of Morals. Translated and edited by Mary Gregor. New York, Melbourne: Cambridge University Press.

Kelsen, H. (1992). Introduction to the Problems of Legal Theory (1934). Translated by Bonnie Litschewski and Stanley L. Paulson. Oxford: Clarendon Press.

Pavčnik, M. (2013). Argumentacija v pravu (Argumentation in Law). (3rd ed.). Ljubljana: GV Založba.

Pavčnik, M. (2015). Teorija prava (Theory of Law). (5th ed.). Ljubljana: GV Založba.

Radbruch, R. (2006). Five Minutes of Legal Philosophy (1945). Translated by Bonnie Litschewski and Stanley L. Paulson. Oxford Journal of Legal Studies, 26(1), 13-15.

Smole, A. (1988). Antigone. Translated by Harry Leeming. Ljubljana: Mladinska knjiga. Visković, N. (1981). Pojam prava (The Notion of Law). (2nd ed.). Split: Logos. 